\title{
MANAGEMENT TECHNIQUES FOR SUPPRESSING HOGPLUM BEETLE BY USING SOME CHEMICALS AND CULTURAL APPROACH
}

\author{
M. M. H. Khan \\ Department of Entomology, Patuakhali Science and Technology University, \\ Dumki, Patuakhali-8602, Bangladesh
}

\begin{abstract}
Experiment on hogplum beetle, Podontia 14-punctata, was carried out to find out the suitable technique(s) for suppressing both larvae and adults of hogplum beetle. Results revealed in field trial that the highest mortality (98.56\%) was found in all larval instars and adult stages of hogplum beetle after 24 hours by the effect of spading + Superior 505 EC (Chlorpyriphos + Cypermethrin) @ 10 $\mathrm{ml} / 10$ liter of water $\left(\mathrm{T}_{2}\right)$ and lowest mortality was recorded in $\mathrm{T}_{3}(83.85 \%)$ treated leaves. The highest infestation reduction over control was obtained from $T_{6}$ $(62.75 \%)$ treated plant compared to other treated plants. In laboratory trial, the highest mortality (96.62\%) was found in all larval instars and adult stages of hogplum beetle after 24 hours by the treatment of superior 505EC $\left(\mathrm{T}_{2}\right)$ followed by $\mathrm{T}_{4}(88.00 \%)$ and lowest mortality was in $\mathrm{T}_{3}(69.70 \%)$ treated leaves. No mortality was observed in control treatment $\left(\mathrm{T}_{5}\right)$.
\end{abstract}

Key words: Hogplum, management technique, chemical, superior 505 EC.

\section{INTRODUCTION}

The fruit of hogplum (Spondias mangifera Wild.) is locally known as Amra which is a popular fruit in Bangladesh. The fruit is delicious and source of vitamin C and carotene (Mondal and Amin 1990). It is consumed in most cases in green stage and is also used as prickle, chattni, murabba, etc. (Ahmad 1969). It is extensively used as fodder in different parts of India like Assam, Madhya Pradesh, Maharashtra, Punjab and Uttar Pradesh (Singh 1982). The hogplum is a deciduous perennial tree with thick succulent leaves and it grows all over the country, but the quality fruits are produced only in the southern districts of Bangladesh (Sarder and Mondal 1983), especially in Barisal and Patuakhali districts. Its cultivation is seriously hampered by hogplum beetle or 14 spotted leaf beetle. The 14 spotted leaf beetle, Podontia quaturdecempunctata or Podontia 14-punctata L. (Chrysomelidae: Coleoptera) is distributed throughout South East Asia and feeds on S. mangifera Wild. (Anacardiaceae) in Bangladesh (Husain and Ahmad 1977, Howlader 1993).

*Author for correspondence: mohasin1965@pstu.ac.bd

(C) 2016 Zoological Society of Bangladesh DOI: 10.3329/bjz.v44i2.32763 
In Bangladesh, the beetles appear in June, abundant during July to September and disappear in October. The peak period of defoliation is August and September (Beeson 1941, Baksha 1997). The beetles cause serious damage to the crop from March to August with two generations in a year (Mondal 1975). Both adults and grubs of this beetle feed on the leaves of the hogplum (Beeson 1941, Ahmed 1969, Mondal 1975, Sarder and Mondal 1983) and heavy infestation often cause complete defoliation of the tree during peak period. Their attack resulting in stunted growth of the plant and eventually reduces the fruit size and yield (Mondal 1975). During severe infestation the larvae devour the old leaves, tender parts of stems, and even the green barks of the plants (Howlader 1993).

At present suitable control measure against this pest is not available in the country. People usually spray insecticides to control this pest. There is no recommended insecticide with proper doses of application. For suppressing this pest and other beetle and weevil pests, some authors tested a few number of chemical insecticides (Hoffmann et al. 2000, Elzen et al. 2000, Singh and Misra 1989), of them malathion was found to be effective against these pests. As this pest is external feeder it is easier to suppress them by using malathion or related insecticides with an appropriate dose(s). But the studies on the determination of suitable insecticides with appropriate doses were not systematically done in laboratory or in field condition so far. Therefore, two doses of Chlorpyrifos, Setap and Superior (Chlorpyriphos + Cypermethrin) were tested to find out the suitable insecticide(s) with proper dose which can effectively suppress the larvae and adult stages of this pest in the laboratory and in field condition.

To develop management technique(s) for suppressing hogplum beetle by using some chemicals and cultural approach at hogplum orchards or farmer's homestead garden of Patuakhali and Barisal districts.

\section{MATERIAL AND METHODS}

Experiment on hogplum beetle, Podontia 14-punctata was carried out in the laboratory of Entomology Department of Patuakhali Science and Technology University (PSTU), Dumki, Patuakhali as well as at the hogplum orchard of Regional Agricultural Research Station (RARS), BARI, Rahmatpur, Barisal, Bangladesh, during April to October, 2013. The laboratory experiment was carried out under normal room temperature $\left(32^{\circ} \mathrm{C}\right)$ and relative humidity $(85 \pm$ $5 \%$ ) with a $14 \pm 2: 10 \pm 2$ light and dark cycle (L : D) following completely randomized design (CRD). The field experiment was laid out in a randomized complete block design (RCBD) with 5 treatments and 3 replications. 
A total of 15 trees of around 6 years old were used for this study. One hogplum tree was considered as one treatment replication. Plant to plant distance was $20 \mathrm{ft} \times 20 \mathrm{ft}$. The evaluated treatments were $\mathrm{T}_{1}=$ Spading + Chita 48 EC (Chlorpyriphos) @ $10 \mathrm{ml} / 10$ liter of water, $\mathrm{T}_{2}=$ Spading + Superior 505 EC (Chlorpyriphos + Cypermethrin) @ $10 \mathrm{ml} / 10$ liter of water, $\mathrm{T}_{3}=$ Spading + Seatap 50 SP @ 15g/ 10 liter of water, T $4=$ Spading + Hitfen 20 EC @10 ml/10 liter of water and $\mathrm{T}_{5}=$ Untreated control. Design of the trial was laid out in RCBD with three replications. A total of three sprays were made at 10 days intervals. Each spray was done by manually driven foot pump sprayer as a full cover spray for the hogplum tree. The leaves, branches and the main trunk of each tree were sprayed with spray mixture through the outlet of the nozzle. Application was made in such a way that the spray pressure would not knock down the pest from the tree. The pre-treatment data were recorded on the number of $1^{\text {st }}, 2^{\text {nd }}, 3^{\text {rd }}$ and $4^{\text {th }}$ instars larvae and adults. Field mortality data on $1^{\text {st }}, 2^{\text {nd }}, 3^{\text {rd }}, 4^{\text {th }}$ instar larvae and adult were recorded at 24 hours after treatment. One square meter $\left(1 \mathrm{~m}^{2}\right)$ quadrat was placed in the central position of the east side canopy structure. The number of adults and larvae was also counted from inside each quadrat under different treatments at one day before the first spray and 1 week after the last spray. The number of healthy and infested leaves was counted from inside each quadrat under different treatments at one day before the first spray and one week after the last spray.

Before applying insecticidal solution, the petiole of fresh succulent mid aged hogplum leaflet was placed inside the plastic pot. Then 10 larvae or 10 adult beetles were released in each plastic pot. When the released larvae or adult beetles started normal movement then the insecticidal treatments viz., $\mathrm{T}_{1}=$ Chita 48 EC (Chlorpyriphos) @ $10 \mathrm{ml} / 10$ liter of water, $\mathrm{T}_{2}=$ Superior 505 EC (Chlorpyriphos + Cypermethrin) @ $10 \mathrm{ml} / 10$ liter of water, $\mathrm{T}_{3}=$ Seatap 50 SP @ $15 \mathrm{~g} / 10$ liter of water, $\mathrm{T}_{4}=$ Hitfen $20 \mathrm{EC} @ 10 \mathrm{ml} / 10$ liter of water and $\mathrm{T}_{5}=$ Untreated control were applied by a hand sprayer as cover spray. Each treatment was replicated 3 times. After treating the leaflet, the mouth of the plastic pot was covered with mosquito net. After application of the treatments, the covered pots were placed on the laboratory table near opened window. Mortality data of $1^{\text {st }}, 2^{\text {nd }}, 3^{\text {rd }}, 4^{\text {th }}$ instar larvae and adult were noted at 24 hours after treatment.

Statistical analysis: Single factor analysis of variance (ANOVA) on different parameters was made following completely randomized design in laboratory trials and randomized complete block design in field trial. Data transformations were done wherever required. Means were compared by LSD test. 


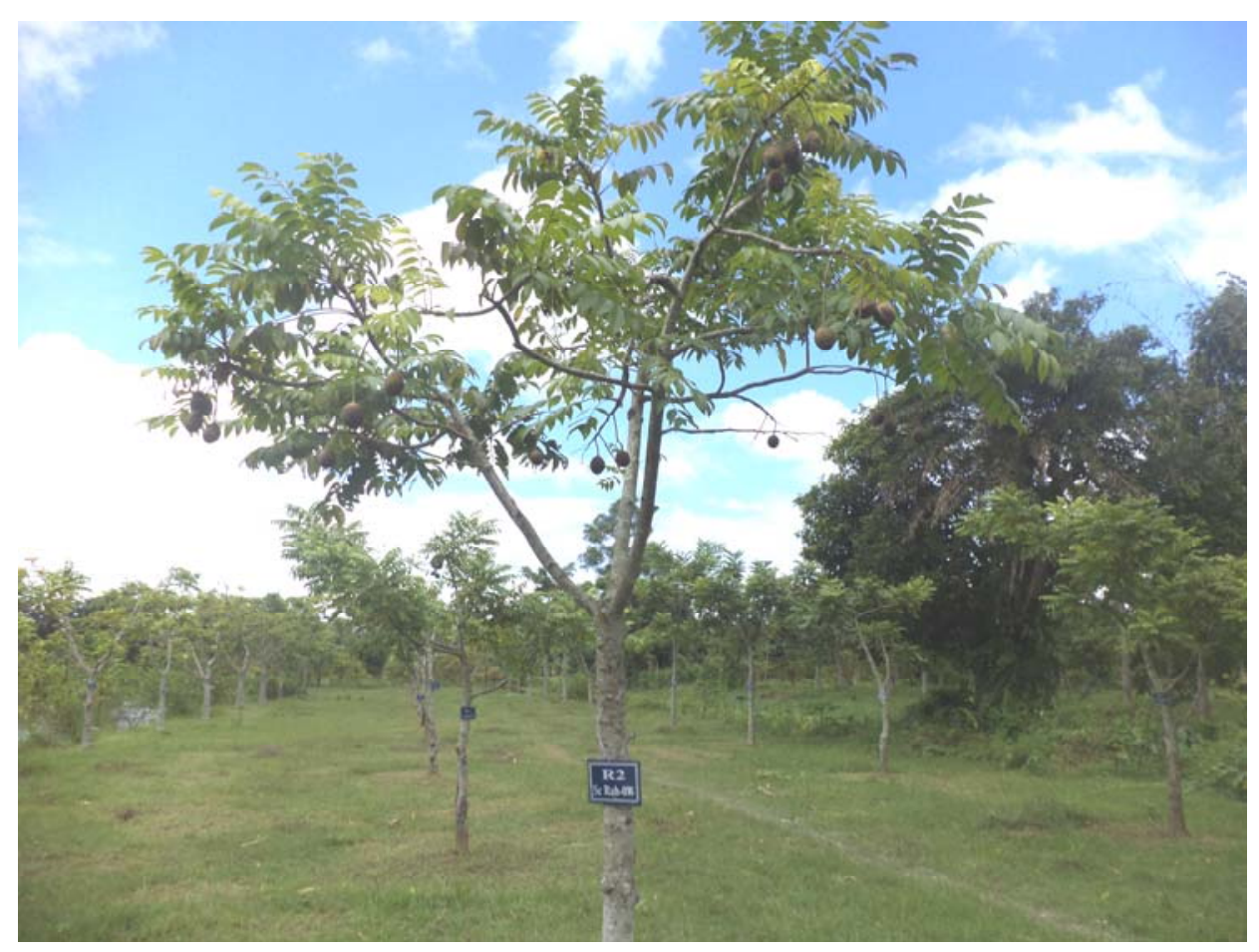

Plate 1. View of experimental field having three replications.

\section{RESULTS AND DISCUSSION}

Effect of different treatments on the mortality of Podontia 14-punctata: The mean mortality of Podontia 14-punctata by the application of different treatments under field condition after 24 hours is presented in Table 1. Significantly the highest mortality $(98.56 \%)$ was found in $1^{\text {st }}$ instar larvae after 24 hours by the effect of spading + Superior 505 EC (Chlorpyriphos + Cypermethrin) @ $10 \mathrm{ml} /$ 10 liter of water $\left(\mathrm{T}_{2}\right)$ followed by $\mathrm{T}_{4}(95.53 \%)$. The lowest mortality was recorded in $\mathrm{T}_{3}(83.85 \%)$ followed by $\mathrm{T}_{1}(88.85 \%)$ treated leaves. No beetle was found dead in control plants $\left(\mathrm{T}_{5}\right)$. Similar trend of mortality was also observed in $2^{\text {nd }}$, $4^{\text {th }}$ and adult stages of hogplum beelte by the application of the same and respective treatments. In case of $3^{\text {rd }}$ instar larvae, the highest mortality was found $\mathrm{T}_{2}$ $(91.67 \%)$ followed by $\mathrm{T}_{4}(86.00 \%)$ and $\mathrm{T}_{3}(81.67 \%)$ treatments. The lowest mortality was recorded in $\mathrm{T} 1(80.67 \%)$ treated leaves and no mortality was observed in control treatment. The results are in agreement with the findings of Mondal (1975) and Sing (1982). Ali (2002) reported that the lower dose $(0.1875 \%)$ of malathion 57 EC were effective for suppression of Podontia 14punctata instead of higher dose $(0.25 \%)$. 
Mortality of Podontia 14-punctata at one week after last spray: The mean number of larvae ranged from 1.5 to 7.6 per square meter of quadrate at one week after last spray (Table 2). No significant difference was observed among treatments regarding per cent leaf infestation at one day before $1^{\text {st }}$ spray. The per cent leaf infestation ranged from 5.01 to 9.82 at one week after last spray. The lowest (5.87\%) leaf infestation was observed in $\mathrm{T}_{6}$ treated plants which was statistically similar to $\mathrm{T}_{5}(5.91 \%)$ treated plants. The highest $(15.76 \%)$ leaf infestation was found in untreated control plants $\left(\mathrm{T}_{7}\right)$ which varied significantly from other treatments. The highest infestation reduction over control was obtained from $\mathrm{T}_{6}(62.75 \%)$ treated plant followed by $\mathrm{T}_{5}(62.50 \%), \mathrm{T}_{2}(56.60 \%)$ and $\mathrm{T}_{1}(53.30 \%)$ treated plants. The lowest infestation reduction over control was obtained from $\mathrm{T}_{3}(40.04 \%)$ treated plant followed by $\mathrm{T}_{4}(46.32 \%)$ treated plant. The findings of the present study are similar with the reports of other authors and they stated that malathion was effective against hogplum beetles (Hoffmann et al. 2000, Elzen et al. 2000, Singh and Misra 1989).

Table 1. Effect of different treatments on the mortality of Podontia 14-punctata after 24 hours under field condition

\begin{tabular}{llllll}
\hline \multirow{2}{*}{ Treatment } & \multicolumn{5}{c}{ Mean per cent mortality in different stage after 24 hours } \\
\cline { 2 - 6 } & $\begin{array}{c}\text { 1st instar } \\
\text { larvae }\end{array}$ & $\begin{array}{c}2^{\text {nd }} \text { instar } \\
\text { larvae }\end{array}$ & $\begin{array}{c}3^{\text {rd }} \text { instar } \\
\text { larvae }\end{array}$ & $\begin{array}{c}4^{\text {th }} \text { instar } \\
\text { larvae }\end{array}$ & Adult \\
\hline $\mathrm{T}_{1}$ & $88.85 \mathrm{c}$ & $83.57 \mathrm{c}$ & $80.67 \mathrm{~b}$ & $78.73 \mathrm{c}$ & $75.94 \mathrm{c}$ \\
$\mathrm{T}_{2}$ & $98.56 \mathrm{a}$ & $96.47 \mathrm{a}$ & $91.67 \mathrm{a}$ & $90.17 \mathrm{a}$ & $90.42 \mathrm{a}$ \\
$\mathrm{T}_{3}$ & $83.85 \mathrm{~d}$ & $79.74 \mathrm{~d}$ & $81.67 \mathrm{ab}$ & $73.04 \mathrm{~d}$ & $72.60 \mathrm{~d}$ \\
$\mathrm{~T}_{4}$ & $95.53 \mathrm{~b}$ & $94.23 \mathrm{~b}$ & $86.00 \mathrm{ab}$ & $83.68 \mathrm{~b}$ & $83.85 \mathrm{~b}$ \\
$\mathrm{~T}_{5}$ & $0.00 \mathrm{e}$ & $0.00 \mathrm{e}$ & $0.00 \mathrm{c}$ & $0.00 \mathrm{e}$ & $0.00 \mathrm{e}$ \\
$\mathrm{CV}(\%)$ & 1.53 & 0.86 & 8.22 & 1.43 & 1.60 \\
Prob. (p) & $\mathrm{p}<0.0000$ & $\mathrm{p}<0.0000$ & $\mathrm{p}<0.0000$ & $\mathrm{p}<0.0000$ & $\mathrm{p}<0.0000$ \\
\hline
\end{tabular}

In a column, means followed by the same letter(s) did not differ significantly as per DMRT.

Values are averages of 3 replications. Treatments: $\mathrm{T}_{1}=$ Spading + Chita 48 EC (Chlorpyriphos) @ 10 $\mathrm{ml} / 10$ liter of water, $\mathrm{T}_{2}=$ Spading + Superior 505 EC (Chlorpyriphos + Cypermethrin) @ $10 \mathrm{ml} / 10$ liter of water, $\mathrm{T}_{3}=$ Spading + Seatap $50 \mathrm{SP} @ 15 \mathrm{~g} / 10$ liter of water, $\mathrm{T}_{4}=$ Spading + Hitfen 20 EC @ 10 $\mathrm{ml} / 10$ liter of water and $\mathrm{T}_{5}=$ Untreated control.

Mortality of Podontia 14-punctata after application of different insecticides under laboratory condition: The mean per cent mortality of Podontia 14-punctata treated with various insecticides under laboratory condition after 24 hours is presented in Table 3. Significantly the highest mortality $(96.62 \%)$ was found in $1^{\text {st }}$ instar larvae after 24 hours by the treatment of superior 505EC $\left(\mathrm{T}_{2}\right)$ followed by $\mathrm{T}_{4}(88.00 \%)$ and $\mathrm{T}_{1}(78.61 \%)$, respectively and the lowest mortality was in $\mathrm{T}_{3}$ $(69.70 \%)$ treated leaves. In case of $2^{\text {nd }}$ instar larvae, the highest mortality (95.29\%) was recorded in $\mathrm{T}_{2}$ treated leaves followed by $\mathrm{T}_{4}(91.97 \%)$ and $\mathrm{T}_{1}$ $(81.00 \%)$, respectively and the lowest mortality was in $\mathrm{T}_{3}(71.34 \%)$ treated 
leaves. In case of $3^{\text {rd }}$ instar larvae, the highest mortality $(99.81 \%)$ was noticed in $\mathrm{T}_{2}$ followed by $\mathrm{T}_{4}(89.81 \%)$ and $\mathrm{T}_{1}(82.86 \%)$, respectively and the lowest mortality was in $\mathrm{T}_{3}(70.89 \%)$ treated leaves.

Table 2. Mortality of Podontia 14-punctata treated with different treatments under field condition after cover spray on hogplum trees at Rahamatpur hogplum orchard during August to September, 2013

\begin{tabular}{|c|c|c|c|c|}
\hline \multirow[t]{2}{*}{ Treatments } & \multirow{2}{*}{$\begin{array}{l}\text { No. of larvae } \\
\text { at 1-WALS }\end{array}$} & \multicolumn{2}{|c|}{ Leaf infestation (\%) at } & \multirow{2}{*}{$\begin{array}{l}\text { Infestation reduction over } \\
\text { control }(\%) \text { at } 1 \text {-WALS }\end{array}$} \\
\hline & & 1-DBFS & 1-WALS & \\
\hline $\mathrm{T}_{1}$ & 7.00 & 8.08 & $5.45 \mathrm{bc}$ & 68.46 \\
\hline $\mathrm{T}_{2}$ & 4.33 & 8.54 & $4.70 d$ & 72.80 \\
\hline $\mathrm{T}_{3}$ & 7.00 & 9.55 & $6.72 b$ & 61.11 \\
\hline $\mathrm{T}_{4}$ & 4.67 & 9.03 & $5.14 \mathrm{bc}$ & 70.25 \\
\hline $\mathrm{T}_{5}$ & 10.33 & 9.29 & $17.28 \mathrm{a}$ & - \\
\hline LSD & - & - & 0.874 & - \\
\hline CV (\%) & - & - & 4.23 & - \\
\hline Prob. (P) & - & NS & $\mathrm{p}<0.05$ & - \\
\hline
\end{tabular}

DBFS $=$ Day before first spray, WALS $=$ Week after last spray. In a column, means followed by the same letter(s) did not differ significantly as per DMRT

Values are averages of 3 replications. Treatments: $\mathrm{T}_{1}=$ Spading + Chita 48 EC (Chlorpyriphos) @ 10 $\mathrm{ml} / 10$ liter of water, $\mathrm{T}_{2}=$ Spading + Superior 505 EC (Chlorpyriphos + Cypermethrin) @ $10 \mathrm{ml} / 10$ liter of water, $\mathrm{T}_{3}=$ Spading + Seatap 50 SP @ 15g/10 liter of water, $\mathrm{T}_{4}=$ Spading + Hitfen 20 EC @ 10 $\mathrm{ml} / 10$ liter of water and $\mathrm{T}_{5}=$ Untreated control.

Table 3. Mortality of Podontia 14-punctata treated with various insecticides under laboratory condition after cover spray

\begin{tabular}{|c|c|c|c|c|c|}
\hline \multirow[b]{2}{*}{ Treatment } & \multicolumn{5}{|c|}{ Mean per cent mortality in different stage after 24 hours } \\
\hline & $\begin{array}{c}1^{\text {st }} \text { instar } \\
\text { larvae }\end{array}$ & $\begin{array}{c}2^{\text {nd }} \text { instar } \\
\text { larvae }\end{array}$ & $\begin{array}{l}3^{\text {rd }} \text { instar } \\
\text { larvae }\end{array}$ & $\begin{array}{l}4^{\text {th }} \text { instar } \\
\text { larvae }\end{array}$ & Adult \\
\hline $\mathrm{T}_{1}$ & $\begin{array}{l}78.61 c \\
(63.20\end{array}$ & $\begin{array}{l}81.00 c \\
(69.87)\end{array}$ & $\begin{array}{l}82.86 c \\
(70.44)\end{array}$ & $\begin{array}{l}77.79 c \\
(61.47)\end{array}$ & $\begin{array}{l}76.70 c \\
(60.36)\end{array}$ \\
\hline $\mathrm{T}_{2}$ & $\begin{array}{l}96.62 \mathrm{a} \\
(81.20)\end{array}$ & $\begin{array}{l}95.29 a \\
(78.37)\end{array}$ & $\begin{array}{l}95.31 \mathrm{a} \\
(77.48)\end{array}$ & $\begin{array}{l}93.67 \mathrm{a} \\
(76.11)\end{array}$ & $\begin{array}{l}88.62 a \\
(74.63)\end{array}$ \\
\hline $\mathrm{T}_{3}$ & $\begin{array}{l}69.70 d \\
(62.36)\end{array}$ & $\begin{array}{l}71.34 d \\
(63.38)\end{array}$ & $\begin{array}{l}70.89 \mathrm{~d} \\
(59.21)\end{array}$ & $\begin{array}{l}69.32 \mathrm{~d} \\
(57.60)\end{array}$ & $\begin{array}{l}66.89 d \\
(56.21)\end{array}$ \\
\hline $\mathrm{T}_{4}$ & $\begin{array}{l}88.00 \mathrm{~b} \\
(77.21)\end{array}$ & $\begin{array}{l}91.97 \mathrm{~b} \\
(85.01)\end{array}$ & $\begin{array}{l}89.81 b \\
(83.44)\end{array}$ & $\begin{array}{l}88.00 b \\
(76.46)\end{array}$ & $\begin{array}{l}86.59 b \\
(74.96)\end{array}$ \\
\hline $\mathrm{T}_{5}$ & $0.00 \mathrm{e}$ & $0.00 \mathrm{e}$ & $0.00 \mathrm{e}$ & $0.00 \mathrm{e}$ & $0.00 \mathrm{e}$ \\
\hline LSD & 0.169 & 0.237 & 0.197 & 0.154 & 0.178 \\
\hline CV (\%) & 5.45 & 6.20 & 5.80 & 4.81 & 4.54 \\
\hline Prob. (p) & $\mathrm{p}<0.05$ & $\mathrm{p}<0.05$ & $\mathrm{p}<0.05$ & $\mathrm{p}<0.05$ & $\mathrm{p}<0.05$ \\
\hline
\end{tabular}

In a column, means followed by the same letter(s) did not differ significantly as per DMRT. Values are averages of 3 replications. Figure in parenthesis are transformed (Arcsine) values.

Treatments: $\mathrm{T}_{1}=$ Chita 48 EC (Chlorpyriphos) @ $10 \mathrm{ml} / 10$ liter water, $\mathrm{T}_{2}=$ Superior 505 EC (Chlorpyriphos + Cypermethrin)@10 ml/10 liter of water, $\mathrm{T}_{3}=$ Seatap 50 SP @ 15 g/10 liter of water, $\mathrm{T}_{4}=$ Hitfen 20 EC @ $10 \mathrm{ml} / 10$ liter of water and $\mathrm{T}_{5}=$ Untreated control. 
In case of $4^{\text {th }}$ instar larvae, the highest mortality $(93.67 \%)$ was noticed in $\mathrm{T}_{2}$ treatment followed by $\mathrm{T}_{4}(88.00 \%)$ and $\mathrm{T}_{1}(77.79 \%)$, respectively and the lowest mortality was in $\mathrm{T}_{3}(69.32 \%)$ treated leaves. In adult stage, the highest mortality $(88.62 \%)$ was also found in treatment $\mathrm{T}_{2}$ followed by $\mathrm{T}_{4}(86.59 \%)$ and $\mathrm{T}_{1}$ $(76.70 \%)$, respectively and the lowest mortality was in $\mathrm{T}_{3}(66.89 \%)$ treated leaves. No dead larvae or adult beetle was observed in control treatment. Mondal (1975) observed that metation at $0.075 \%$ active ingredient killed maximum beetles and about $93.33 \%$ of them were found dead. Singh (1989) described that $0.25 \%$ malathion is the most effective dose against adult hogplum beetle. Ali (2002) reported that the lower dose $(0.1875 \%)$ of malathion 57EC may be recommended for effective suppression of Podontia 14-punctata instead of higher dose (0.25\%). Hoffmann et al. (2000) and Lissy-o et al. (2000) found that ultra low volume of Malathion has been used as an essential tool for boll weevil, Anthonomus grandis Boheman eradication programme in the USA.

\section{CONCLUSION}

From the findings of this study it can be concluded that all treatments showed more or less similar toxic effects on the larvae and adult beetles of hogplum beetle. Superior 505EC (Chlorpyriphos + Cypermethrin) @10 ml/10 liter of water may be recommended for effective management of hogplum beetle in field and laboratory. Spading + Superior 505 EC (Chlorpyriphos + Cypermethrin)@10 ml/10 liter of water could be used as an effective technique for suppressing hogplum beetle in field condition.

Acknowledgement: This paper is a part of a research project. The author is grateful to the University Grants Commission of Bangladesh for financial assistance to carry out the research work during project period.

\section{LITERATURE CITED}

AHMAD, K. 1969. Minor fruits of East Pakistan. In: Flowers, fruits and vegetables. (Ed. 2). Sharbajanin Granthalay, Government New Market, Dhaka. 344 pp.

ALI, M. Z. 2002. Studies on the mating and oviposition behavior of hogplum beetle Podontia 14punctata and its chemical control. M.S. Thesis, Department of Entomology, Bangabandhu Sheikh Mujibur Rahman Agricultural University, Gazipur.

BAKSHA, M. W. 1997. Biology, ecology and control of Amra defoliator, Podontia quaturdecimpunctata Linn. (Chrysomelidae: Coleoptera) in Bangladesh. Bangladesh J. For. Sci. 26 (1): 43-46.

BEESON, C. F. C. 1941. The ecology and control of forest insects of India and neighboring countries. Government of India Press, Delhi. 229pp.

ELZEN, G. W., MALDONADO, S. N. and ROJAS, M. G. 2000. Lethal and sub-lethal effects of selected insecticides and an insect growth regulator on the boll weevil (Coleoptera: Curculionidae) ectoparasitoid Catolaccus grandis (Hymenoptera: Pteromalidae). J. Econ. Entomol. 93 (2): 300303. 
HOFFMANN, W. C., W.KIRK, I., DUGGER, P. and RICHTER, D. 2000. Sunlight protection for ULV Malathion. Proceedings Beltwide cotton Conferevces, San Antonio, USA 2: 1356-1358.

HOWLADER, M. A. 1993. Growth, development and survival of Podondia quaturdecempunctata L. (Chrysomelidae: Coleoptera) larvae on different parts of host plant. Bangladesh J. Zool. 21: 1-7.

HUSAIN, M. and AHMAD, M. 1977. Notes on chrysomelid beetles (Coleoptera) of the Bangladesh Agricultural University area, Mymensingh. Bangladesh J. Zool. 5: 71-75.

LISSY-O, E. L., KISER, D., DUGGER, P. and RICHTER, D. 2000. The use of malathion ULV in Texas boll weevil eradication programs. Proceedings Beltwide cotton Conferevces, San Antonio, USA, 2: 1069-1071.

MONDAL, M. A. 1975. Studies on the biology and control of fourteen spotted leaf beetle, Podontia 14punctata (Coleoptera: Chrysomelidae) on the hogplum. M.S. Thesis, Department of Entomology, Bangladesh Agricultural University, Mymensingh.

MONDAL, M. A. and AMIN, M. R. 1990. "Phaler Bagan". Ed. By Mrs. Afia Mondal, Club building (First floor), BAU campus, Mymensingh (in Bengali). 215 pp.

SARDAR, M. A. and MONDAL, A. 1983. Bio-ecology and chemical control of Podondia 14-punctata (Linn.) on hogplum. Indian J. Agric. Sci. 53 (8): 745-748.

SINGH, P. and MISRA, R. M. 1989. Bionomics of the ambara defoliator Podondia 14-punctata Linn. (Coleoptera: Chrysomelidae). Indian Forester 115 (12): 910-915.

SINGH, R. V. 1982. Fodder trees of India. Oxford and IBH Publishing Co. 663 pp.

(Manuscript received on 15 May, 2016; revised on 31 December, 2016) 